\title{
ОКРЕМІ АСПЕКТИ СУТНОСТІ ІЕНДЕРУ В СУДДІВСЬКІЙ ДІЯЛЬНОСТІ: ДО ПОСТАНОВКИ ПРОБЛЕМИ
}

Постановка проблеми. Сучасна наука розрізняє поняття стать та гендер. Традиційно стать використовують для позначення анатомо-фізіологічних особливостей людей на основі яких вони визначаються як чоловіки або жінки. Нинішне ж розуміння поняття гендеру зводиться до соціальної моделі жінки та чоловіка, яка визначає статус та роль у суспільстві та надає чоловікам притаманні маскулінні риси, форми поведінки, професії, а жінкам - фемінні. Питання гендерної симетрії набуло чималої популярності у різних галузях суспільних наук, стало темою безлічі наукових досліджень, однак, на сьогодні не $є$ вирішеним в Україні, в тому числі та в судовій системі. Хоча з курсом євроінтеграції, останнім часом, розвиток гендерного законодавства в Україні відбувається досить швидко - практичне ж вирішення та подолання гендерної нерівності потребує чималих зусиль та копіткої праці. Закон краще відкликатиметься усім членам суспільства у випадку подолання гендерної асиметрії у судовій системі та представленні у повній мірі в судах достойних та талановитих чоловіків та жінок суддів.

Стан дослідження проблеми. Поряд з розмаїтістю та численністю опублікованих праць 3 гендерної проблематики спостерігається відсутність комплексного правового бачення цього феномену, не вистачає фундаментальних робіт, у яких був би представлений цілісний аналіз різних аспектів статусу судді, у тому числі та жінки в сучасному українському суспільстві. Крім того, загальнотеоретичні питання гендерної рівності суддів ще не були предметом наукового інтересу вітчизняних науковців. Вказане зумовлює актуальність цього дослідження.

Правовим аспектам гендерної рівності в Україні присвячені праці вітчизняних та закордонних вчених-гендеристів - С. Айвазової, Н. Аніщук, Н. Болотіної, М. Буроменського, О. Вороніної, В. Глиняного, О. Дашковської, Л. Завадської, Л. Кормич, Н. Лавріненко, І. Лаврінчук, К. Левченко, Л. Леонтьєвої, Т. Марценюк, О. Матвієнко, Т. Мельник, Н. Оніщенко, Л. Петришиної, Н. Пушкарьової, С Поленіної, О. Руднєвої, З. Ромовської, Л. Смоляр, Г. Терещенка, М. Томашевської та інших.

Виклад основного матеріалу. «Три речі можна вважати щастям: що ти не дика тварина, що ти грек, а не варвар, та що ти чоловік, а не жінка» - відомі слова Сократа людині [1, с. 30]. Натомість іншою є думка про те, що жінка - це не марне повторення чоловіка, а зачароване місце, де здійснюється живий зв'язок людини з природою. Якби жінки зникли й чоловіки залишилися самі, то стали б чужинцями без паспорта в крижаному світі. Вона - сама земля, піднесена до верховіть життя, земля, що стала відчутною й радісною, а без неї земля чоловіка - німотна й мертва [2].

Аналізуючи трансформаційні процеси, що відбуваються в сучасному суспільстві загалом та їхній вплив на нинішню ґендерну картину, варто зазначити, що останню важко визначити як однорідну та чітко структуровану, вона характери- 
зується полярними ґендерними стереотипами, появу та функціонування яких спричинили економічні, політичні, культурні зміни у суспільстві. Відповідно, характер впливу гендерних стереотипів не завжди можна однозначно визначити як конструктивний чи деструктивний, оскільки їхні вияви можуть бути як позитивними, так та негативними за своїми наслідками для суспільства в цілому та його членів, зокрема [3].

Беззаперечно, стать являє собою біологічно (генетично) зумовлений поділ людей на чоловіків та жінок. Відповідно до записки Генерального секретаря, складеної за підсумками тридцятої сесії Комітету з ліквідації дискримінації у відношенні жінок, стать - соціальне поняття, що характеризує біологічні статеві відмінності, але при цьому також ідеологічна та культурна концепція, відтворена у сфері матеріальної практики, відповідно, впливає на результати такої практики. Вона зачіпає розподіл ресурсів, багатства, роботи, повноважень у сфері прийняття рішень та політики та користування правами та пільгами в сім’ї та суспільному житті. Попри обумовлені культурою та часом відмінності, відносини між статями у світі передбачають асиметрію влади чоловіків та жінок як однієї з характерних особливостей. Таким чином, стать є одним із соціальних чинників стратифікації, та в цьому сенсі він схожий на інші диференціальні фактори, такі, як раса, клас, етнічна та статева належність та вік. Вона допомагає нам зрозуміти соціальну будову статевої самоідентичності та нерівність структури влади, що лежить в основі відносин між статями [4].

Окрім біологічних відмінностей між людьми існує поділ їх соціальних ролей, форм діяльності, відмінностей у поведінці та емоційних характеристиках на «типово чоловічі» або «типово жіночі», що охоплюється поняттям гендер (сукупність соціальних та культурних норм, які суспільство наказує виконувати людині в залежності від їі біологічної статі). Диференціація понять стать та ґендер означала вихід на новий теоретичний рівень осмислення соціальних процесів.

3 моменту народження людина перебуває під впливом наявної ґендерної системи, де новонароджених хлопчиків більше годують, зате з дівчатками більше розмовляють, перших з народження вчать бути справжніми козаками, а других принцесами. У процесі виховання сім'я (в особі батьків та родичів), система освіти (в особі виховательок дитячих установ та вчителів), культура в цілому (через книжки й засоби масової інформації) впроваджують у свідомість дітей ґендерні норми, формують певні правила поведінки та створюють уявлення про тому, хто є «справжній чоловік» та якою має бути «справжня жінка». Так та напрошується загальновідомий вислів 3. Фрейда «анатомія - це доля» .

Зрештою сам термін «ґендер» не замінює терміна «стать», його використовують для аналізу ролей, відповідальності, обмежень, можливостей та потреб чоловіків та жінок в усіх сферах та в будь-якому окремому соціальному контексті. Він не має аналогів ані в українській, ані в російських мовах, є словом іншомовного походження, що прижилося у сучасному українському суспільстві. Слово «Гендер» походить від грецького «генос» та в перекладі означає походження, матеріальний носій спадковості, той, що народжує.

Загалом попри різноманіття Іендерних наукових концепцій, для більшості 3 них базовим положенням є розрізнення понять «стать» та «ґендер». Перше означає 
суто анатомічні й фізіологічні особливості, відмінності побудови й функціонування жіночого й чоловічого тіла, організму. Друге - психологічну й соціальну відмінність між жінками й чоловіками як представниками певної культури [5, с. 174].

У Великому тлумачному словнику сучасної української мови слово «ґендер» має два значення: відмінність між чоловіками та жінками за анатомічними ознаками або ж - соціальний розподіл, який часто базується на статевих відмінностях, але не обов'язково збігається з ними [6].

До слова, термін «ґендер» виник у Великій Британії, та в дослівному перекладі з англійської мови означає граматичний рід. Надалі дане поняття мало соціостатеві характеристики статі на відміну від біологічних. Гендер стосується не тільки чоловіків та жінок, як окремих індивідів, а й характеризує відносини між ними як соціальними групами та гендерні відносини в цілому - те, як реалізуються соціальні ролі обох статей, як вони соціально вибудовуються. Без глибокого усвідомлення поняття гендеру неможливо підійти до аналізу проблем рівності статей.

Нині в іспанській, італійській, французькій мовах для визначення статевої приналежності використовується слово «sex», а в англійській мові, де немає чоловічого, жіночого чи середнього роду використовується для цього слово «Гендер». Українським аналогом слова іноземного походження «ґендер» $є$ рід, вид, приналежність до певного виду статі, набір характеристик поведінки для тієї чи іншої статі. Щоправда, виникають розбіжності щодо написання слова «гендер». У багатьох словниках цей термін зафіксований під літерою «г», тоді як існує певна кількість вітчизняних наукових досліджень, де це слово розпочинається з літери «Г». Нами обрано останній варіант, враховуючи останні зміни до українського правопису.

Для повноти картини звернемо увагу, на те, що поняття «ґендер» показує одночасно «<...> складний соціокультурний процес продукування суспільством різниці в чоловічих та жіночих поведінкових ролях, в їх ментальних та емоційних характеристиках та власне його результат - соціальний конструкт гендера» [7, с. 10].

Окрім цього, одні вчені розглядають «ґендер» як сукупність біологічних та фізіологічних ознак статі; інші взагалі вважають такий термін неприйнятним, але визнають «жіночі дослідження» як самостійний напрям. Більшість дослідників вважає, що гендер, на відміну від поняття статі, стосується не суто біологічних чи анатомічних властивостей, за якими відрізняються чоловіки й жінки, а соціально сформованих рис «жіночості» та «мужності», тобто поняття «гендер» означає психологічну, соціальну та культурну відмінність між чоловіками й жінками [8, с. 67].

При цьому, згідно з Джок'якартськими принципами гендерна ідентифікація становить «внутрішне та глибоко індивідуальне сприйняття кожною особою своєї статі, що може збігатися або не збігатися зі статтю, яку було задокументовано при народженні, включаючи особисте відчуття свого тіла (що може охоплювати, за вибором особи, модифікацію зовнішнього вигляду чи функцій тіла шляхом медичного, хірургічного або іншого втручання) та інші прояви гендеру, враховуючи одяг, мову та манери" [9].

До слова, ґендерна рівність вперше дістала нормативне закріплення у першій програмі $\mathrm{OOH}$ «Розвиток жінок», що базувалася не лише на гендерних дослідженнях, а й на висновках молекулярно-клітинних біологів, що зазначали, що в крові 
чоловіків на рівні популяції рівень тестостерону невпинно знижується, а в жінок підвищується [10].

Використання поняття «ґендер» та гендерного підходу у тому числі у судовій діяльності означає оцінювання того, які наслідки для чоловіків та жінок матиме здійснення тієї чи іншої дії, чи то впровадження нового законодавства (змін до нього), певної державної політики тощо та включає:

- інформацію про ґендерні питання (судова ґендерно-чутлива статистика);

- ґендерний аналіз (оцінка впливу ґендеру під час здійснення тих чи інших дій);

- гендерний паритет в управлінні;

- ґендерна освіта працівників суду.

Інтеграція ґендеру у судову систему покликана вирішити ряд наступних задач:

- забезпечення рівного доступу до правосуддя чоловіків та жінок;

- виконання державою своїх ґендерних зобов'язань в рамках міжнародного права;

- урахування конкретних потреб в галузі судочинства, характерних всім групам суспільства;

- забезпечення довіри до системи правосуддя;

- репрезентативність та легітимність судової системи;

- реформування законів, що передбачають дискримінацію, укріплення захисту прав людини;

- гарантії невідворотності покарання винних в насиллі на ґендерному грунті.

Сучасні теорії гендерних відносин доводять, що соціальні відмінності між чоловіками та жінками «не мають біологічного походження, не є одвічно даними, а лише набутими, приписаними індивідові суспільством» [11, с. 19].

Саме поняття «ґендер» має множинний та ситуативний характер. Уявлення про те, що означає бути жінкою чи чоловіком, змінюється залежно від контексту [12, с. 139-140]. Гендерний вимір характеризується передусім рівністю жіночої та чоловічої соціальних статей. Встановлення такої рівності на практиці вимагає подолання патріархальних стереотипів, статевої ієрархічності соціальних зв’язків, в яких чоловіки заздалегідь сприймаються як вищі за розумовими та фізичними здібностями істоти, їхня діяльність є найбільш значущою та пріоритетною у порівнянні з діяльністю жінок [13, с. 91].

Щоправда, у «потоці» публікацій з ґендерної тематики не можна не помітити величезної кількості тлумачень поняття ґендер та його похідних, що утруднює правильне його розуміння, а часом взагалі призводить до гносеологічного парадокса, коли повністю ігнорується сутність даного поняття [14, с. 465].

Попри наявність певного кола визначень та ознак того, що сьогодні зветься «ґендерна рівність», «дискримінація», універсальної формули-дефініції цих понять не існує, оскільки їх сприйняття змінюється залежно від геополітичних чинників, культурних традицій, моральних та правових цінностей суспільства й законодавства держав. Дискримінація може бути або de jure aбо de facto, або одночасно двох цих видів. De jure передбачає наявність дискримінаційних положень у чинному законодавстві. De facto означає, що при закріпленому в законодавстві принципі рівноправності чоловіків та жінок, певні його положення не виконуються 
або відсутня система гарантій реалізації прав, не визначено гендерного компонента в компетенції певних державних органів, не встановлено спеціального механізму реалізації даного права.

Гендерна рівність є процесом справедливого відношення до жінок та чоловіків та означає, що жінки та чоловіки мають однаковий суспільний статус, однакові умови для реалізації всіх прав людини, однакові можливості робити внесок у національний політичний, економічний, соціальний розвиток та користуватися його результатами.

Нормативне ж визначення поняття гендеру вперше надано у Законі «Про рівність статей у Боснії та Герцеговині», ухваленому Парламентською асамблеєю Боснії та Герцеговини 21 червня 2002 року, яким встановлюється, підтримується та захищається рівність статей та гарантуються рівні можливості для всіх як у громадському, так та в особистісному житті, а також усуваються та запобігаються прояви прямої та непрямої дискримінації за статтю. Стаття 4 цього закону надає таке визначення гендера: соціально-сформовані ролі чоловіків та жінок у громадському та приватному житті, які значною мірою зумовлені їх біологічними відмінностями [15].

Ото ж, ґендер - це суспільно-соціальна система цінностей, норм та характеристик чоловічої та жіночої поведінки, стилю життя та способу мислення, ролей та відносин жінок та чоловіків, набутих ними як особистостями в процесі соціалізації, що насамперед визначається соціальним, політичним, економічним та культурним контекстами буття та фіксує уявлення про жінку та чоловіка залежно від ї статі.

Таким чином, розглядаючи людину крізь ґендерну призму ми зможемо побачити сукупність вихідних даних, згідно з якими особа позиціонується як суспільний індивід та визначається їх очікувальна діяльність у соціумі, що є наслідком процесу їх соціалізації.

Висновки. Підсумовуючи зазначимо, що саме визначення поняття «ґендер» лягло в основу розуміння гендерної асиметрії в суддівській діяльності, де він проходить червоною канвою та лягає в основу її змістового розуміння. А й справді, диференціація за ознакою статі, яка на перший погляд не має чіткого вираження при більш грунтовному її вивченні знаходить свій прояв чи не у всіх аспектах суспільного та державницького життя, не оминаючи та судову систему.

Для того, щоб судова система мала легітимність в очах населення України, необхідно, щоб їі кадровий склад відбивав склад того суспільства, якому вона повинна служити. На даний час жінки не в повній мірі представлені в судах вищого рівня та на керівних посадах в судах.

\section{Jimepamypa}

1. Гендерний підхід : історія, культура, суспільство / ред. Л. Гентош. Львів : ВНТЛ-Класика. 2003. $250 \mathrm{c}$.

2. Карруж M. URL: http://kristina-sikora.blogspot.com/2010/04/blog-post_21.html

3. Вілкова О.Ю. Конструктивні та деструктивні вияви гендерних стереотипів. Український центр політичного менеджменту. Грудень, 2011. URL: http:// www.politik.org.ua/vid/magcontent. $\mathrm{php} 3 ? \mathrm{~m}=8 \& \mathrm{n}=53 \& \mathrm{c}=1131$ 
4. Итоги тридцатой сессии Комитета по ликвидации дискриминации в отношении женщин. Записка Генерального секретаря URL: http://www.un.org/womenwatch/daw/csw/csw48/crp3-r.pdf.

5. Андріїв В. Жінки та ринок праці : деякі гендерні аспекти. Рівність жінок та чоловіків в Україні. Правові аспекти: матеріали міжн. наук. - практ. конф. (Київ, 20-21 лист. 2000 р.) / Упр. гуманіт. розвитку Секретаріату Каб. Мін. України, проект ПРООН «Сприяння ґендерній рівності», Ініціативна гендерна група у Верховній Раді України, Всеукр. громадська організація «Ліга жінок - виборців України «50/50». Київ : Логос, 2001. С. 174-177.

6. Великий тлумачний словник сучасної української мови / укладач та гол. ред. В. Т. Бусел. Київ; Ірпінь : ВТФ «Перун», 2001. 1440 c.

7. Воронина О.А. Феминизм и гендерное равенство. Москва : Эдиториал УРСС, 2003. 320 с.

8. Попов М.П. Механізми державного управління в сфері гендерної політики: міжнародний досвід та перспективи України. Актуальні проблеми політики: Зб. наук. пр Одеса : Фенінс, 2005. Вип. 24. С. 65-77.

9. Джокьякартские принципы применения международно-правовых норм о правах человека в отношении сексуальной ориентации и гендерной идентичности. URL: http://www.yogyakartaprinciples. org/principles_ru.pdf.

10. 0 структуре «OOH-женщины» URL: http://www.compet.kh.gov.ua/images/MTD/Katalogi/ EOS_forum.pdf

11. Кісь О. Дефініції фемінізму. Незалежний культурологічний часопис «Ї». 2000. № 17. С. 19

12. Кіммел М. Відмінні інституційні контексти використовують та породжують різні форми маскулінності та фемінності. Гендероване суспільство / Пер. з англ. Київ : Сфера, 2003. 494 с.

13. Оніщенко Н., Матвієнко О. Гендерні правовідносини: поняття, сутність, природа та значення. Держава та право. юрид. та політ. науки: Зб. наук. пр. Київ : Ін-т держави та права ім. В.М. Корецького НАН України, 2006. Вип. 33. С. 90-96.

14. Кутова Н.А. Гендер та освіта. Жінка в Україні: Міжвід. наук. зб. / за ред. А.І. Комарової та ін. Київ : Друкарський відділ наук.-дослід. інституту «Проблеми людини», 2001. Т. 23. С. 465-489.

15. Про рівність статей : Закон Боснії та Герцеговини від 21 черв. 2002 p.

16. Мельник Т. М. Міжнародний досвід гендерних перетворень. Київ : Логос, 2004. С. 178-186.

\section{Анотація}

Боброва Ю. Ю. Окремі аспекти сутності гендеру в суддівській діяльності: до постановки проблеми. - Стаття.

У статті піднімається проблематика гендерного виміру суддівської діяльності в контексті таких питань як ґендерна дискримінація, ґендерна рівність, ґендерна асиметрія за статевою ознакою. Оскільки ключовим поняттям досліджуваної проблеми є гендер, то приділено увагу розкриттю змісту та сутності цього поняття як міжгалузевого феномену.

Ключові слова: суд, суддя, ґендер, суддівська діяльність, жінка, чоловік.

\section{Аннотация}

Боброва Ю. Ю. Отдельные аспекты сущности гендера в судейской деятельности: к постановке проблемы. - Статья.

В статье поднимается проблематика гендерного измерения судейской деятельности в контексте таких вопросов как гендерная дискриминация, гендерное равенство, гендерная асимметрия по половому признаку. Поскольку ключевым понятием исследуемой проблемы является гендер, то уделено внимание раскрытию содержания и сущности этого понятия как межотраслевого феномена.

Ключевые слова: суд, судья, гендер, судейская деятельность, женщина, мужчина.

\section{Summary}

Bobrova $Y u$. Yu. Some aspects of the essence of gender in the judiciary: before the problem. - Article.

The article raises the issue of gender dimension of judicial activity in the context of such issues as gender discrimination, gender equality, and gender asymmetry. Since the key concept of the problem under study is a gender, attention is paid to the disclosure of the content and essence of this concept as an interbranch phenomenon.

Key words: court, judge, gender, judiciary, woman, man. 